\title{
Enzymuria in a population living near a cadmium battery plant
}

\author{
L Järup, M D Carlsson, C G Elinder, L Hellström, B Persson, A Schütz
}

Department of Environmental Health and Infectious Diseases Control, Karolinska Hospital, Stockholm, Sweden Lars Järup

Kalmar University, Department of

Natural Sciences, Kalmar, Sweden and Local Government of Mönsterås,

Environmental

Protection Board,

Mönsterås, Sweden

Margareta Dea Carlsson

Department of Renal

Medicine at the

Karolinska Institute,

Huddinge University

Hospital, Huddinge,

Sweden

Carl Gustaf Elinder

Department of Public

Health, County

Council of Kalmar,

Oskarshamn, Sweden

Lennart Hellström

Department of

Occupational and

Environmental

Medicine, Linköping

University Hospital,

Linköping, Sweden

Bodil Persson

Department of

Occupational and

Environmental

Medicine, University

Hospital, Lund,

Sweden

Andrejs Schütz

Correspondence to:

Dr L Jarup, Department of Environmental Health and Infectious Diseases Control, Karolinska Hospital, MME

S-17176 Stockholm,

Sweden.

Accepted 29 June 1995

\begin{abstract}
Objectives-To study the body burden of cadmium and signs of tubular dysfunction in a rural population living near a closed nickel cadmium battery plant.

Methods-Cadmium and $N$-acetyl- $\beta$ glucosaminidase (NAG) in urine were measured in 72 subjects who lived close to the plant.

Results-Residents living close to the plant had higher median urinary cadmium concentrations than those living farther away $(1.01 \quad v \quad 0.46 \mathrm{nmol} / \mathrm{mmol}$ creatinine) and than a control group $(0.2 \mathrm{nmol} / \mathrm{mmol}$ creatinine). There was a significant correlation between urinary cadmium and the excretion of NAG in urine as well as signs of tubular dysfunction in residents who excreted urinary cadmium above $0.5 \mathrm{nmol} / \mathrm{mmol}$ creatinine.

Conclusion-Tubular dysfunction may appear in environmentally exposed subjects at lower cadmium body burdens than previously anticipated.
\end{abstract}

(Occup Environ Med 1995;52:770-772)

Keywords: environmental exposure; urinary cadmium; $N$-acetyl- $\beta$-glucosaminidase

It is well established that exposure to cadmium may cause kidney damage leading to renal failure and secondary skeletal decalcification (renal osteomalacia). ${ }^{1}$ The initial sign of the cadmium induced renal lesion is a tubular proteinuria, usually detected as an increased excretion of the protein $\beta_{2}$-microglobulin ${ }^{2}$ or other markers-such as, $a_{1}$-microglobulin, ${ }^{3}$ retinol-binding protein (RBP), ${ }^{4}$ and $\mathrm{N}$-acetyl$\beta$-glucosaminidase $(\mathrm{NAG})^{5}$-in urine. It has recently been reported that occupational ${ }^{6}$ as well as environmental ${ }^{7}$ exposure to cadmium at lower concentrations than previously anticipated may lead to renal dysfunction. The aim of this study was to investigate the cadmium body burden and signs of early tubular dysfunction in a population living near a closed nickel cadmium battery plant.

\section{Methods}

In 1910, an accumulator factory was established in the south east of Sweden where cadmium was produced until 1974. From 1912 to
1967, an electrochemical wet process was used and the cadmium emission to the environment during that period was estimated at 3.6 tons. In 1960 , a different production process started, where metallic cadmium was oxidised in an open flame. The total estimated cadmium emissions to the air from this process were estimated at 4.5 tonnes. $^{9}$

The study population included 72 people ( 29 men and 43 women, 28 to 88 years old), who had lived within $1 \mathrm{~km}$ of the factory area for at least five years between 1912 and 1974 . People who had worked at the factory were excluded. Only 10 people were current smokers. We analysed separately the effect (tubular function) on those people who lived closer than $500 \mathrm{~m}$ from the plant ( $n=17$ ) and those who lived further away $(n=55)$ to elucidate the occurrence of renal dysfunction among people who live in the vicinity of cadmium plants. No separate control group was established for this study, but for comparison we used a previously studied group of male industrial workers $(n=35$, aged 24 to 68,11 of whom were current smokers) not exposed to cadmium, from a region not far from the study area (Schütz et al, unpublished observations).

Morning urine samples were collected directly in cadmium free, wide necked polyethylene bottles. Subsamples of $10 \mathrm{ml}$ were poured into cadmium free polypropylene tubes, $0.2 \mathrm{ml}$ concentrated nitric acid was added, and the samples were kept frozen until analysis. Cadmium-114 was measured with inductively coupled plasma mass spectrometry (ICP-MS, Fisons VG Plasmaquad PQ2) after dilution of the samples 10 times with $2 \%$ nitric acid. Correction was made for interference from tin. Indium was used as the internal standard. Analysis of a control sample of lyophilised urine (Seronorm batch 009024, Nycomed AS, Oslo, Norway), gave $5.0 \mu \mathrm{g} / 1$ compared with the recommended $5 \cdot 5 \mu \mathrm{g} / 1$.

The NAG in urine was analysed with a fluorometric method. For NAG, it has been suggested that $2.7 \mathrm{U} / \mathrm{g}$ creatinine $(=0.31$ $\mathrm{U} / \mathrm{mmol}$ creatinine) ${ }^{9}$ or $3.6 \mathrm{U} / 24 \mathrm{~h}$ (approximately $0.3 \mathrm{U} / \mathrm{mmol}$ creatinine) ${ }^{6}$ should be used as the cut off point for detection of tubular dysfunction. Other authors have proposed $4.0 \mathrm{U} / \mathrm{g}$ creatinine $(=0.45 \mathrm{U} / \mathrm{mmol}$ creatinine $)^{10}$ In this study, $0.5 \mathrm{U} / \mathrm{mmol}$ creatinine was chosen as the cut off limit for tubular dysfunction.

Standard statistical analysis was performed with the SPSS/Windows and Statistica statistical packages. 
Figure 1 Median urinary cadmium values in non-smoking people who live at different distances from a Swedish cadmium plant.

Figure 2 NAG in urine as a function of urinary cadmium in environmentally exposed people.
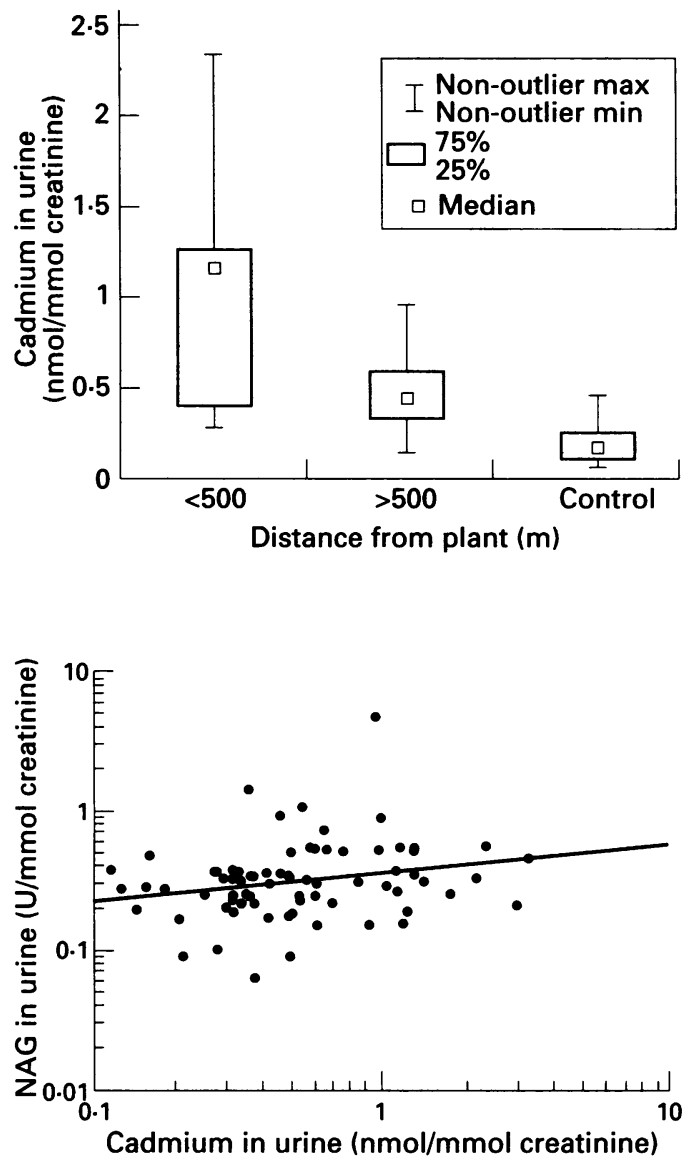

Results

The urinary cadmium concentrations ranged from 0.12 to $3.23 \mathrm{nmol} / \mathrm{mmol}$ creatinine (mean (SD) $0.70(0.61)$ ). The NAG values in urine ranged from 0.06 to $4.72 \mathrm{IU} / \mathrm{mmol}$ creatinine (mean (SD) $0.42(0.56)$ ).

The median urinary cadmium concentrations were $1.01 \mathrm{nmol} / \mathrm{mmol}$ creatinine in people living closer than 500 metres from the plant $(\mathrm{n}=17)$ and $0.46 \mathrm{nmol} / \mathrm{mmol}$ creatinine in those living further away $(n=55)$. The median difference was almost significant $(P=0.052)$. In the control group $(n=35)$, the median urinary cadmium was $0.2 \mathrm{nmol} / \mathrm{mmol}$ creatinine. The median difference between these two groups was highly significant $(\mathrm{P}=0.0002)$.

Figure 1 shows the distribution of urinary cadmium in the three groups, smokers excluded.

Figure 2 shows the relation between urinary cadmium and the excretion of NAG in urine,

Dose-response relation between urinary cadmium and enzymuria in people living close to a cadmium battery plant.

\begin{tabular}{llllll}
\hline $\begin{array}{l}\text { Urinary } \\
\text { cadmium } \\
\begin{array}{l}\text { (nmollmmol } \\
\text { creatinine) }\end{array}\end{array}$ & $\begin{array}{l}\text { Mean } \\
\text { age }\end{array}$ & Smokers & $\begin{array}{l}\text { Total } \\
\text { number of } \\
\text { people }\end{array}$ & $\begin{array}{l}\text { People } \\
\text { with NAG } \\
>0.5\end{array}$ & $\begin{array}{l}\text { Prevalence of } \\
\text { tubular } \\
\text { dysfunction (\%) }\end{array}$ \\
\hline$<0.5$ & 65 & 2 & 37 & 2 & 5.4 \\
$\geqslant 0.5$ & 64 & 8 & 35 & 14 & 40.0 \\
\hline
\end{tabular}

all subjects included. The corresponding regression equation was:

$\ln (\mathrm{NAG})=-1.0+0.20 \times \ln (\mathrm{U}-\mathrm{Cd})$ $(P=0.0497)$

A dose-response relation between cadmium in urine and the excess excretion of urinary NAG was found (table).

\section{Discussion}

Recently, a growing concern has arisen that tubular dysfunction may occur at lower concentrations than previously estimated in populations environmentally exposed to cadmium. ${ }^{7}$ From the published 24 hour data by Staessen et $a l,{ }^{8}$ we computed the geometric mean of urinary cadmium values to be 0.66 for control area subjects and $0.81 \mathrm{nmol} / \mathrm{mmol}$ creatinine for subjects from a polluted area, the prevalence of renal dysfunction increased the less the distance from the cadmium emitting plants. Our study shows geometric means of 0.48 (median $=0.46$ ) and 0.75 (median $=1.01) \mathrm{nmol} / \mathrm{mmol}$ creatinine, respectively, for two groups at different distances from the plant, similar to the Belgian findings ${ }^{8}$. Furthermore, the urinary cadmium concentrations in the present study were significantly higher than in a Swedish control group.

There was significant correlation between urinary cadmium and the excretion of NAG in urine with no evidence of a threshold as was found in a recent Belgian study. ${ }^{12}$ The regression slope was less accentuated than in the study by Bernard et al ${ }^{12}$ possibly because we measured total NAG instead of the more specific NAG-B isoenzyme.

There was also a suggestion of an increased prevalence of urinary NAG excretion among those living close to the plant. We therefore plan to extend the study size and to include other measures of exposure (in soil, drinking water, etc) and effect (tubular function) to further elucidate the occurrence of renal dysfunction among people living in the vicinity of cadmium plants.

The study was financed by the Swedish Environmental Protection Agency. We thank the primary health care personnel at Fliseryd who collected the data.

1 Friberg L, Elinder CG, Kjellström T, Nordberg GF. Cadmium and health: a toxicological and epidemiological appraisal. Boca Raton: Florida CRC Press, 1986:2.

2 Kjellström T, Evrin PE, Rahnster B. Dose-response analysis of cadmium-induced tubular proteinuria: a study of urinary $\beta_{2}$-microglobulin excretion among workers in a battery factory. Environ Res 1977;13:303-17.

3 Nogawa $K$, Kido T, Yamada Y, Tsuritani I, Honda $R$ Ishizaki $M$, et al. $a_{t}$-Microglobulin in urine as an indicator of renal tubular damage caused by environmental cadmium exposure. Toxicol Lett 1984;22:63-8.

4 Lauwerys RR, Bernard A, Roels HA, Buchet JP, Viau C. Characterization of cadmium proteinuria in man and Environ Health Perspect 1984;54:147-52.

5 Nogawa K, Yamada Y, Honda R, Tsuritani I, Ishizaki M Sakamoto $M$. Urinary $N$-acetyl- $\beta$-D-glucosaminidase Sakamoto M. Urinary $N$-acetyl- $\beta$-D-glucosaminidase
and $\beta_{2}$-microglobulin in 'itai-itai' disease. Toxicol Lett
$1983 ; 16: 317-22$.

6 Järup L, Elinder CG. Dose-response relations between urinary cadmium and tubular proteinuria in cadmium urinary cadmium and tubular proteinuria in cadm

7 Buchet JP, Lauwerys R, Roels H, Bernard A, Bruaux P, Claeys F, et al. Renal effects of cadmium body burden of the general population: published erratum in Lancet 1991;337(8756):1554. Lancet 1990;336:
699-702. 
8 Staessen JA, Lauwerys RR, Ide G, Roels HA, Vyncke G, Amery A. Renal function and historical environment cadmium pollution from zinc smelters. Lancet 1994;343 1523-7.

9 Bergbäck B, Carlsson M. Heritage of cadmium and leadA case study of a Swedish accumulator factory. Sci Total Environ 1995;166:35-72.

10 Bernard AM, Roels H, Cardenas A, Lauwerys R Assessment of urinary protein 1 and transferrin as early markers of cadmium nephrotoxicity. Br f Ind Med 1990, m7:559-65.
11 Klein G. Ergebnisse der multizentrischen Ermittlung vorl:aufiger Referenzbereiche für- $\beta$ - $N$-Acetylglucosaminidase im Urin von Erwachsenen. (Results of multicenter determination of preliminary reference values for $\beta$-N-acetylglucosaminidase in urine of adults). Wien Klin Wochenschr Suppl 1991;189: 50-1

12 Bernard A, Thielemans $N$, Roels $H$, Lauwerys $R$. Association between NAG-B and cadmium in urine with no evidence of a threshold. Occup Environ Med 1995; 52:177-80.

융 